\title{
HEBREWS 6:4-8: A SOCIO-RHETORICAL INVESTIGATION (PART 2)
}

\author{
David A. deSilva
}

\begin{abstract}
Summary
The first part of this essay established the importance of patron-client roles and expectations for the argument being advanced in Hebrews 6:4-8. Having been privileged to receive such gifts from God, the addressees could not now respond in such a way as would bring dishonor on their patron. Such a course would not only be unjust, but also ultimately disasterous. This second part now considers the ideological texture of the passage, particularly how the author re-engineers the parameters within which the hearers are to consider what will be advantageous for them. The real danger to their safety comes not from perseverance with a marginalized group, but from disloyalty to the patron-client bond God has formed with them. The author thus significantly advances his agenda of motivating perseverance to the end of the journey begun at their conversion and baptism. Finally, the theological debates concerning Heb 6:4-8 are critiqued in light of the social context of patronage: 'eternal security' and 'impossibility of restoration' are both seen to be positions that ultimately transgress the dynamics of a carefully nuanced system.
\end{abstract}

\section{The Socio-Rhetorical Strategy of Hebrews 6:4-8}

Having explored prominent aspects of the inner texture, intertexture, and social and cultural texture of Hebrews, it remains to look at the ideology of this passage. How has the author, in responding to what he perceives to be the crucial need of the audience's situation, shaped their perception of that situation so as to motivate them to follow the course he promotes? How has he offered them a view of reality which brings them closer to 'seeing things his way' and to acting as he would have them act? In answering these questions, we will also have an opportunity to review the rhetorical strategy of the author. Finally, what will be the social effects of Hebrews 6:4-8, if the hearers accept 
the author's presentation of their situation and the course they must follow?

Hebrews 6:1 had proposed an overarching agenda for the addressees - being carried along to completion, the end of the journey begun by their conversion, baptism, and early catechesis in the Christian world-view (6:1-2). This is another way of expressing what the author has held forward as the essential significance of life in this world from the beginning ('inheriting salvation', 1:14; entering 'glory', 2:10; 'entering God's rest', 4:1-11). In all of these images, the author chooses an expression which seeks to propel the hearers forward in the journey they have begun. The images themselves convey the importance of 'pressing on', and work to counter the consideration of the advantages of 'quitting' or even 'soft-pedalling' one's Christian commitments. Recalling the essential elements of the 'foundation' of the audience's secondary socialisation into the norms of the Christian culture cannot be accidental or merely ornamental. Each basic tenet or ritual serves to reinforce those contours of churchshaped reality which make the author's agenda the 'wise' and advantageous course of action to follow, and all opposing courses foolish and disadvantageous. This is particularly true of the last tenets, namely the teaching on 'resurrection of the dead' and 'eternal judgement'. The hearers must consider advantage and disadvantage not only in terms of this visible world, but also in terms of the circumstances one may find oneself in after death and for eternity.

6:4-8 underscores the necessity of accepting the author's agenda as proposed in 6:1. To those who ask, 'why should we press on to the completion of this journey, this partnership, which continues to cost us so much in terms of our life among the non-Christian majority', the author has prepared a striking and uncompromising answer. Response to God's word, and now more broadly the complex of God's gifts and endowments which the hearers have hitherto enjoyed, emerges as the single most important consideration (i.e., what the author wants his audience to bear foremost in their minds) in their deliberations. Once again, the author moves into a consideration of the danger of not moving forward in trust and loyal obedience (see also $2: 1-4 ; 3: 7$ 4:13). This is now painted even more fiercely than in previous iterations in what has become celebrated as one of the hardest passages of Scripture. The author's depiction of the 'contrary' is all the more striking when we consider that the addressees were not being asked to deny Christ in some public trial before a magistrate, but were merely succumbing to the pressures quietly to hide their association 
with this minority group. .55 The author asserts that merely 'drifting off' or 'shrinking back' is as good as hoisting the Son of God up on the cross and inviting more mocking and jeering. Simply leaving the voluntary association called the 'church' becomes an active assault on the honour of one's divine benefactor and mediator.

This rather more dramatic portrayal of the courses of action open to the addressees invites a number of what Aristotle called 'special' deliberative topics which the author now brings to bear in support of his exhortation (6:1). ${ }^{56}$ Most prominently, he is appealing to the topic of Justice, and particularly the subtopic of gratitude (obligations to one's benefactors) ${ }^{57}$ Not making a fair return to one's benefactor was unjust; to act so as to inflict dishonour upon one who had been a benefactor is an even more egregious act of injustice. This leads the author to the topic of the expedient. ${ }^{58}$ There is no recovery of the present goods which are enjoyed for the one who, thinking the course of 'falling away' to be advantageous, is willing to throw them away and thus shame the benefactor. ${ }^{59}$ Such a person will 'in reality' act contrary to what is expedient, exchanging present goods for future, certain evils (6:8). 'Drifting away' is shown to be unjust and, ultimately, disadvantageous. The hearers, therefore, will be inclined toward what the author depicts as the just course, namely that of

55 See Attridge, Hebrews, 171, n. 58.

56 These topics were employed to make the alternative course seem unattractive and the proposed course seem the more attractive. A course of action was promoted by demonstrating it to be any combination of just, expedient, lawful, feasible, honourable, pleasant, and necessary; an audience would be dissuaded from a course of action by showing it to be the opposite of these. See Aristotle, $R h$. 1.4-1.7; Rhet. Her. 3.2.2-3.4.9; Rhet. Alex. 1421b21-1423a12.

57 Rhet. Alex. 1421b37-1422a2: 'What is just is the unwritten custom of the whole or the greater part of mankind, distinguishing honourable actions from base ones. The former are to honour one's parents, do good to one's friends and repay favours to one's benefactors; for these and similar rules are not enjoined on men by written laws but are observed by unwritten customs and universal practice'; Rhet. Her. 3.3.4: 'We shall be using the topics of Justice ...if we show that it is proper to repay the well-deserving with gratitude; ... if we urge that faith (fidem) ought zealously to be kept; if we maintain that ties of hospitality, clientage, kinship, and relationship by marriage must inviolably be cherished; if we show that neither reward nor favour nor peril nor animosity ought to led us astray from the right path.... By their contraries we shall demonstrate that an action is unjust.'

58 Rhet. Alex. 1422a4-7: 'What is expedient is the preservation of existing good things, or the acquisition of goods that we do not possess, or the rejection of existing evils, or the prevention of harmful things expected to occur'; $c f$. Aristotle $R h .1 .7$ on relative expediency.

59 The exclusion of a 'second' chance may also be read as an attempt to remove a potential motive for wrongdoing, namely the possibility of an indulgence (Aristotle, Rh. 1.12.15). 
continuing as a loyal, trusting client of God (6:1) and making a fair return for God's benefits $(6: 7,9-10)$, which will also result in the preservation of goods already enjoyed and the acquisition of greater goods.

The author also paints the course of 'shrinking back', of failing to press on to the completion of their Christian pilgrimage, as unpleasant and unsafe: the fire of 6:8 (underscored at 10:26-31) becomes the danger which the disloyal client, who foolishly exchanged the pleasant experiences of God's goodness and favor (6:4-5) for the unpleasant experience of punishment, must face. Perseverance in commitment to God and the Christian group is depicted as the course which 'ensures the avoidance of a present or imminent danger'60 (imminent because of the apocalyptic expectations of this author and the early Christian community; see 10:25, 37), while hiding or setting aside one's open association with that group leads to danger at the arrival of 'the coming one' (10:37-39; the fire of 6:8 and 10:27).

To those contemplating the advantages of not pursuing the Christian hope any further, the author holds up the irreversible exclusion from benefits to which such a course would lead. The addressees are led to consider movement away from the Christian group not in terms of how this will decrease tension between them and the host society, but in terms of how it will create and exponentially escalate tension between themselves and the Son who awaits the subjection of his enemies. They are led to consider it not as a move toward what their neighbours would consider just and pious, but as a movement toward the utmost injustice and impiety toward one who had gone to the most extreme lengths (death itself) to bring them the benefits which they now so carelessly spurned. The agricultural metaphor goes further than 6:4-6 (the impossibility of restoration), positing fiery retribution and curse as the end stage of that course of action (a most striking contrast with 'deliverance', 'glory', and 'rest').

The author gains substantial ground by insisting that teaving the Christian group will not mean escaping the Christian world view or the consequences of their actions before God. It is not merely a matter of human relationships that they must consider, nor what human beings can do to them (see 13:5-6), but what God is capable of doing to those who wilfully spurn God's gifts and dishonour his Son. Leaving the Christian group does not mean leaving the sphere of God's reach, but only the sphere of God's favor! It becomes apparent

60 Rhet. Her. 3.2.3. 
that the author is herein also making an appeal to the emotions (an appeal to pathos), specifically using the arousal of fear to advance his goal. ${ }^{61}$ Responding with ingratitude to (specifically, acting disloyally so as to bring dishonour upon) one who has already showered great gifts and privileges upon the hearers would justifiably arouse the anger of the benefactor. ${ }^{62}$ Hebrews $6: 8$ especially articulates 'imminent evil that causes destruction or pain' 63 as the result of affronting the virtuous benefactor. The impossibility of help (Aristotle $R h$. 2.5.12), here that it is 'impossible to restore' such a person 'to repentance', also enhances fear through the removal of its opposite, confidence. The author thus seeks to make the hearers afraid to take the path of dissociation from the Christian group and from open association with the name of Jesus, to make them 'feel' as well as 'reason' that such a path is disadvantageous (being both unjust and dangerous). This point will be amplified and reinforced in 10:26-31; 12:16-17, 25-29.

To what end does the author employ this richly-textured, dense, and complex strategy? He seeks to maintain the commitment to the Christian group of each individual member in the face of ongoing opprobrium and hostility from voices outside the Christian group. The host society has been engaged in its own strategy, namely that of shaming deviants back into conformity with the values of that larger body $(10: 32-34 ; 12: 1-11)$. There would be some 'advantage' to breaking off associations with the Christian group, as this would reduce and quite possibly remove the tension which exists between the (ex-)Christian and his or her non-Christian neighbours. ${ }^{64}$ The author replaces the alternatives which potential deserters consider (tension and loss in society versus acceptance again among neighbours) with a new set of alternatives (blessing versus curse, promise versus destruction) so as to maintain the integrity of the sectarian group.

61 See Aristotle, $R h .2 .5$, for a discussion of ways in which a speaker might cultivate this emotional response in his or her audience.

62 Aristotle $(R h .2 .2 .8,17)$ introduces this as a general rule, and Hebrews' interpretation of $\mathrm{Nu} .14$ certainly introduces this principle into the sermon. Especially salient is Aristotle, $R h$. 2.2.23: anger can be roused against the ungrateful, as their slights are 'contrary to all sense of obligation'. This 'anger' will re-emerge as a more forceful motivator in Heb. 10:26-31.

63 Aristotle $(R h .2 .5 .1)$ presents this as an essential ingredient for the stimulation of an emotional response of fear.

64 On this aspect of the addressees' situation, and the author's strategy for defusing society's shaming techniques, see deSilva, Despising Shame, chapter 4. 
Moreover, the author goes on in 6:9-10 to concretise his own religious or metaphorical language in 6:7-8. He has here, in effect, drawn out for the audience what the 'real-life' counterparts to bearing suitable vegetation are. The hearers have been producing 'suitable vegetation' for those for whose sake they were being cultivated by means of God's gifts, namely for their Christian family. As they have made, and continue to make, a 'just' return for God's benefits, God will not be 'unjust' to forget their nobility as clients. The passage therefore also serves the goal of shaping the kind of community which fosters sufficiently strong internal bonds and effectively marshals aid to withstand opposition from outside the group. 65 This, too, is a recurring emphasis of Hebrews $(3: 12-13 ; 10: 24-25 ; 13: 1-3,16)$.

\section{Theological Implications}

While I am critical of the efforts of several authors who have blunted the impact of this passage in their attempts to integrate these verses into their theology, I am not unsympathetic to the troubling questions raised by Hebrews 6:4-8 which prompts such harmonising and which makes this passage an enduring stumbling block to affirmations of God's mercy, love, forgiveness, and even sovereignty. Therefore, I am impelled to address the theological questions raised by this passage, hoping that doing so from the insights gained through socio-rhetorical analysis will afford a new perspective on the passage and the theological enterprise itself.

In an earlier article, I suggested that the rhetorical situation governed the application of this text (together with the other warning passages of Hebrews). ${ }^{66}$ The author is addressing the hearers with this warning precisely to motivate them not to undervalue the benefits they have received and will receive from God such that they reject these in favor of a return to the world's friendship. He is not addressing those who had withdrawn, as he would consider it, unreclaimably. Hebrews 6:9-10 itself makes this clear. Those who 'hear his voice' and 'do not harden their hearts' (Heb. 3:7) may still reach the good end that God has prepared for them. To use this passage, then, as a basis for trying to determine when someone has crossed the point of no return, or to apply it so as to debar from the church those who do in fact repent, would be to remove the warning from its rhetorical setting.

65 For further discussion, see deSilva, Despising Shame, 284-89, 310-11.

66 'Exchanging Favor for Wrath', 116. 
Further investigation of the ethos of reciprocity, however, leads me to rather more bold conclusions about Hebrews 6 and theological debate both concerning 'eternal security' and the 'impossibility of repentance' (or 'unforgivable sin'). In his lengthy unfolding of the complex dynamics of patronage and reciprocity (and, particularly, how to act honourably within that relationship), Seneca frequently articulates what can only be described as a 'double-mindset'. He appears at many points not to let the right hand know what the left is thinking. Clients are advised to think one way, patrons another-and if these mindsets get mixed up or crossed, the beauty of reciprocity, the gracefulness of grace, becomes irreparably marred.

Speaking to the benefactor, Seneca says: 'In benefits the bookkeeping is simple-so much is paid out; if anything comes back, it is gain, if nothing comes back, there is no loss. I made the gift for the sake of giving' (Ben. 1.2.3). The giver is to adhere to the principle that benefits are given not with an eye to the giver's advantage, so that beneficiaries are not to be chosen on the basis of who will make the most profitable return. However, this is independent from the question of the obligation of the receiver and the ugliness of ingratitude (Ben. $2.25 .3 ; 3.1 .1)$. The point is that the giver should only be concerned with giving for the sake of the other, while the recipient should be concerned with showing gratitude to the giver. If either viewpoint is compromised (that is, if the client attenuates his display of gratitude based on the detachment the patron should keep from such considerations), reciprocity ceases to be noble and becomes ugly. This different set of 'rules' for giver and recipient in the social 'game' of reciprocity is made explicit in several passages:

The one should be taught to make no record of the amount, the other to feel indebted for more than the amount (Ben. 1.4.3).

In the case of a benefit, this is a binding rule for the two who are concerned - the one should straightway forget that it was given, the other should never forget that it was received (Ben. 2.10.4).

Let the giver of a benefit hold his tongue; let the recipient talk (Ben. 2.11.2).

In cases where a recipient has taken great pains to try to return a benefit, being watchful and thoughtful for the opportunity but simply not finding a way to help one who is far greater than himself or herself,

the one should consider that he has received the return of his benefit, while the other should know that he has not returned it; the one should release the other, while the other should feel himself bound; the one should say, 'I have received', the other, 'I still owe' (7.16.1-2). 
Seneca displays these different and even contrary mindsets in order to

keep before us the public good; the door must be closed to all excuses, to keep the ungrateful from taking refuge in them and using them to cover their repudiation of the debt. 'I have done all in my power', says he. Well, keep on doing so... You have done everything in order to make return; this should be enough for your benefactor, it should not be enough for you. For, just as he is unworthy of being repaid with gratitude if he permits all your earnest and diligent effort to pass as nothing, so, if anyone accepts your goodwill as full payment, you are ungrateful if you are not all the more eager to acknowledge your indebtedness because he has released you $(7.16 .2,4)$.

The purpose of this lengthy inquiry of Seneca is to show that the author of Hebrews moves in a social ethos in which recipients of benefactions are led to act with one set of considerations in view (namely, the importance of maintaining a response of gratitude and avoiding any course which would show ingratitude toward a patron) while benefactors are led to act with another set of considerations in view (with an emphasis on exercising generosity and magnanimity). This strengthens, I believe, my earlier observation that the rhetorical situation of Hebrews (as an address to clients of the divine Patron urging the maintenance of loyalty and obedience) must govern its application and appropriation.

On one crucial point, however, Seneca contradicts both Dio Chrysostom and Hebrews. ${ }^{67}$ The latter authors assert that those who have insulted or affronted their benefactor will be excluded from future favours (Dio, Or. 31.38, 65; Heb. 6:4-6; 10:26-31; 12:16-17). Seneca, however, promotes a willingness to help those who have shown themselves ungrateful in the past:

although we ought to be careful to confer benefits by preference upon those who will be likely to respond with gratitude, yet there are some that we shall do even if we expect from them poor results, and we shall bestow benefits upon those who, we not only think will be, but we know have been, ungrateful (Ben. 1.10.5).

He develops this later as the means by which a truly noble spirit shows itself-by imitating the gods:

he has not repaid me with gratitude; what shall I do?' Do as the gods, those glorious authors of all things, do; they begin to give benefits to him who knows them not, and persist in giving them to those who are ungrateful... Let us imitate them; let us give, even if many of our gifts have been given in

67 Significantly, Seneca also 'contradicts' himself, since he has already discussed the plight of the ingrate as one who sees himself or herself as 'marked' by society and unable to participate in the social game of reciprocity (Ben. 3.17.1-2, quoted above). This shows that the answer to the question 'does the ingrate ever have another chance at gaining favour' will be different, depending on which side of the court one is playing on (patron or client). 
vain; none the less, let us give to still others, nay, even to those at whose hands we have suffered loss $(7.31 .2,4) .68$

If a man is ungrateful, he has done, not me, but himself, an injury... what I have lost in the case of one man, I shall recover from others. But even to him I shall give a second benefit, and, even as a good farmer overcomes the sterility of his ground by care and cultivation, I shall be victor... It is no proof of a fine spirit to give a benefit and lose it; the proof of a fine spirit is to lose and still to give! (7.32).

What accounts for Seneca's affirmation of restoring the ingrate to favor, something which his near-contemporaries regard as impossible? It is the different audience and rhetorical situation. Seneca is addressing benefactors in these passages, directing them to their models for generosity (namely the gods, who pour rain 'on the just and the unjust') and to what would constitute honourable action for the givers. Dio, like the author of Hebrews, is addressing clients who are in danger of committing ingratitude against their benefactors. In such a situation, the desideratum is to motivate immediate remedies for ingratitude and the pursuit of a response of gratitude. It would not serve in such situations to discourse on the ability of any high-minded benefactor to overlook slights and affronts, since such considerations would not spur the hearers on to the course which Dio and the author of Hebrews urge. 69

Thus Seneca proves relevant to the ultimate question of sin and repentance apart from the rhetorical strategy of Hebrews 6 . Seneca (Ben. 7.32) even employs an agricultural metaphor, now in a way quite different from Ben. 1.1.2 (or Heb. 6:7-8), to motivate benefactors to continue to show generosity toward the ungrateful-to cultivate virtue in the ingrate by surprising generosity. But Seneca consistently distinguishes between what considerations ought to guide the benefactor and what considerations the recipient should keep

68 Cf. Mt. 5:44-48, especially on this point of what to do when not repaid.

69 In response to the question of Heb. 6 and the limits on God's mercy, Attridge (Hebrews, 172) says: 'In taking this stance, our author unjustifiably limits the gracious mercy of God, and the church's later position on the possibility of repentance and reconciliation seems to be more solidly founded in the gospel message.' Our exploration of Seneca suggests, however, that even such a balanced assessment may offer an inappropriate criticism of the author of Hebrews. He is not addressing the ultimate question of how far God's generosity extends, since to do so would be to violate what is emerging as an important rule of the patron-client social game: the client is never to act so as to presume upon the patron's generosity or magnanimity. Both Dio (with regard to human patrons, whose favour would be 'unjustifiably limited' by Dio by the same token) and Hebrews focus fully on what clients need to ' $k$ now' in order to do their part-that they have received favours, and must respond with gratitude if they hope for future favours. 
before his or her eyes. This sort of social game preserves the nobility of the system, and helps us resolve the problem of interpreting and applying Hebrews 6 . The author was shaped by, and writes within, a world in which the relationship between clients and patrons, and by extension human beings and the ultimate Patron, is described dynamically rather than systematically, in which the declaration that the ingrate is forever excluded from favor stands alongside the exhortation to benefactors to be generous even to the ungrateful, if by some means surprising generosity may win the ingrate over to a noble response of loyalty, respect, and service. Both considerations, though apparently contradictory, serve what was for the authors of our texts the higher goal of sustaining commitment to act honourably within the system of reciprocity.

The doctrine of eternal security certainly crosses the line from the perspective of Seneca, for pondering the expectation that a patron will be lenient and indulgent threatens to foster half-heartedness in the clients, who can too easily excuse themselves from making a fair return (particularly if it becomes inconvenient or costly). To teach that God would not ever give even the apostate a second chance also crosses the line, for patrons remain free to show favor on whom they will. Neither frame of reference is appropriate for Hebrews, which was formulated rather within the cultural context of patron-client scripts, in a world where such roles were fundamental to the functioning of society. The author of Hebrews wants to motivate his hearers to remain loyal and honourable clients of the Lord who gave them unprecedented access to God (as well as other great benefits), and arms them with the arguments and sentiments that will facilitate their completing their part of the reciprocal relationship nobly and reliably. Like Seneca (Ben. 7.16.2), the author wishes to close the door on every excuse for ingratitude, to eliminate every possible motive for responding to God basely and disloyally.

We should not make Hebrews 6:4-8 to have less force than it did for its first hearers, and many discussions of the passage written from the perspective of a conviction of 'eternal security' seek to do exactly that. The text assumes the possibility that a person can fall away after receiving God's gifts, and after participating as fully as anyone can in what blessings of the next age are open for our experience in this age. With the cultural context of patronage and reciprocity, such a course as brings open disgrace on the benefactor who has in all things acted reliably and nobly should be regarded as the ultimate crime against goodness, a vice for which there are no remedies nor sufficient 
penalties. We should, however, also not make Hebrews 6:4-8 to say more than it does. It does not reveal the ultimate condition of the benefactor's mind, for he may always choose to extend forgiveness. Seneca shows us, however, that, when speaking to clients, one must promote one set of attitudes and trajectories, and that, when speaking to patrons, one may promote different attitudes (and these are, in Seneca at least, frequently contradictory).

These considerations are offered in the hope that a long-standing problem in biblical theology may be settled-in favor of not attempting to settle it. Once the tension is resolved one way or the other, the beauty of grace, both as God's favor and our response, is threatened. 